\title{
PEMANFAATAN MEDIA PEMBELAJARAN DALAM MENINGKATKAN KUALITAS PEMBELAJARAN PAI DI SEKOLAH
}

\begin{abstract}
Abstraks:
Oleh: In this globalization era, education technology programs, especially in Indonesia, Arfandi have spread so quickly, not only in the level of basic education but also to the level of education at the college level. As an indication of the development of education Email: technology, among others, there have been many different types of media learning arfandi.1985@gmail.com

Fakultas Tarbiyah Universitas Ibrahimy in improving the quality of learning such as visual media, audio media, and audiovisual media. Of the various instructing media, all of which can support in the process of activities in learning and teaching, but the very urgent attention by every educator is that the use of the media not only look at the sophistication but more important is the quality of the implementation of learning activities in an educational institution, of course, it is necessary to adapt to some targets that are the mission of education. It is very important for a teacher in carrying out his duties as a teacher must have pedagogic competence, a teacher should have the ability to be in accordance with the methodology of learning both in terms of learning planning and in the implementation of learning. So, a teacher who already bas competence and qualifications in both the mastery and ability in the use of learning media that will certainly affect the process of teaching actively, innovative, creative, and enjoyable.
\end{abstract}

Keywords: PAI Learning, Learning Media Utilization

\section{PENDAHULUAN}

Pendidikan dapat diartikan sebagai sebuah komunikasi, mengingat salah satu dalam kegiatan belajar mengajar tersebut mempunyai beberapa komponen diantaranya adalah komponen komunikator, komponen komunikan, dan komponen pesan (message),. Secara terminologi arti dari komunikasi yang diambilkan dari bahasa Inggris adalah communication, dan juga komunikasi yang berasal dari kata latin adalah communicatio, yang memiliki makna pemberitahuan (informasi), bila dilihat secara konseptualisasi maka dapat dipahami bahwa istilah dari komunikasi dapat dipahami dengan sebuah pengertian pemberitahuan dan penyebaran informasi, pemahaman, fikiran-fikiran, dengan tujuan untuk memberikan stimulus untuk ikut serta dalam berpartisipasi agar apa yang diinformasikan itu bisa menjadi pemahaman bersama. Di era globalisasi ini dinamika ilmu pengetahuan dan teknologi sudah semakin canggih, bahkan dinamika yang terjadi di masyarakat, baik perkembangan dari pengalaman cara anak dalam belajar, ditandai dengan kecanggihan teknologi media komunikasi dan informasi dan lainlainya tentu hal ini akan berdampak terhadap kegiatan pendidikan ayang ada di sekolah. Oleh karena itu, sangat penting untuk melakukan beberapa pendekatan secara teknologis dalam rangka untuk melakukan inovasi-inovasi baik dalam hal pengelolaan pendidikan maupun pengelolaaan pembelajaran yang lebih efektif dan efisien.

Pendekatan teknologis menjadi sangat penting dalam pelaksanaan pengelolaan pendidikan dengan tujuan bagaimana nantinya bisa membantu dalam proses pendidikan untuk memperoleh capaiancapaian dalam tujuan pendidikan itu sendiri, yakni yang disebut dengan istilah al-insan al-kamil. Dengan demikian, pendidikan merupakan salah satu bagian yang tidak terpisahkan dari sebuah kebudayaan yang merupakan salah satu dalam mengimplemintasikan nilai-nilai keislaman maupun dalam mengemukaan argumentasi-argumentasi yang tentunya hal ini akan memberikan kemampuan dalam berpartisipasi dalam dinamika nilai-nilai dalang rangka untuk menjadikan bangsa dan negara ini lebih maju. Salah satu upaya 
dalam menjadikan pendidikan yang efektif dan efesien yaitu dengan cara meningkatkan kualitas guru dan pembelajaran. Oleh karena itu, sangat penting untuk menjadikan guru agar mempunyai komptensi dan kualifikasi dengan tujuann untuk menjadikan guru tesebut menjadi berkualitas. Salah satu indikator dari serang guru yang memilki kulaitas adalah serang guru yang memiliki kompetensi dan kualifikasi dalam mewujudkan tercapainya apa yang menjadi tujuan dari pendidikan nasional itu sendiri, ${ }^{1}$ sebagaimana yang tertuang dalam UU RI No. 14 Tahun 2005 seorang guru harus mempunyai kualifikasi dan komptensi, baik kompetensi kepribadian, pedaggik, kompetensi sosial, dan kompetensi profesional.

Kompetensi pedagokik yang dimiliki oleh guru tentu hal ini akan menjadikan guru benar-benar harus mempunyai kompetensi baik secara metodologis maupun secara konseptualis dalam rangka untuk mengaplikasikan perencanaan pembelajaran dan pelaksanaan pembelajaran yang efektif dan efesien. Salah satu yang harus dikuasai oleh seorang guru adalah bisa memanfaatkan dalam penggunaan media pembelajaran yang ada di lembaga pendidikan. Banyak dari kalangan praktisisi pendidikan menyebutkan bahwa Penggunaan media pembelajaran yang baik dan benar akan sangat memberikan dampak dalam kegiatan belajar mengajar baik kegiatan yang ada di dalam maupun kegiatan yang nada di luar kelas, salah satu dampaknaya adalah meningkatnya minat belajar siswa yang pada akhornya ada peningkatan yang lebih baik dalam hal prestasi siswa. Di zaman globalisasi ini program teknologi pendidikan khususnya di Indonesia telah menyebar dengan begitu cepatnya, dengan diawali oleh pendidikan tingkat dasar sampai tingkat pendidikan tinggi. Hal ini di tandai oleh salah satu ciri adanya perkembangan teknologi pendidikan tersebut antara lain telah banyak digunakan berbagai jenis media pembelajaran dalam implementasi kegiatan belajar mengajar, sehingga hal ini mencapai satu target secara optimal dari tujuan pendidikan.

Perkembangnya teknologi pendidikan yang semakin canggih ini serta kemajuan ilmu dan perubahan gerakan dinamika pembagunan maka bidang media ini mempunyai nilai yang

\footnotetext{
1 Yudhi Munadi, Media Pembelajaran (Jakarta: Gaung Persada Press, 2008), 1.
}

amat tinggi untuk digunakan sebagai penyalur pesan pendidikan sekolah. ${ }^{2}$ keberdaan media pembelajaran dalam kegiatan belajar mengajar sangan penting keberadaan dari media itu, karena dengan adanya media akan sangat membantu bagi siswa dalam belajar matari apapun dan tentunya juga akan berdampak terhadap keaktifan dalam belajar yang pada akhirnya akan ada peningktan prestasi bagi para siswa. Kehadiran media dalam kegiatan belajar mengajar tentu akan sangat membantu bagi seorang guru dalam menjelaskan materi pelajaran yang sulit dicerna oleh setiap siswa, tidak dapat dipungkiri kehadiran media belajar sengat bermanfaat baik bagi guru dalam menyampaikan materi pelajaran dan juga bermanfaat bagi siswa dalam memahami pelajaran yang diajarkan oleh guru.

\section{PEMBAHASAN}

\section{Meningkatkan Kualitas Pembelajaran}

Dalam aktivitas pembelajaran ada unsur yang sangat urgen yaitu adanya unsur belajar dan unsur mengajar. Belajar dapat dimaknai sebagai aktifitas yang akan menghasilkan pengetahuan dan pengalaman. ${ }^{3}$ Mengajar dimaknai dengan kegiatan yang dilakukan oleh sesorang untuk mendidik, membimbing dalam kegiatan belajar. Dengan demikian, dua unsur belajar dan mengajar adalah merupakan salah satu interaksi antara seorang guru dengan siswa yang disebut dengan istilah pembelajaran atau kegiatan belajar mengajar.

Ada beberapa definisi tentang pembelajaran (proses belajar mengajar) yang dikemukakan oleh para ahli, sebagaimana yang di sampaikan oleh Hasibuan bahwa pembelajaran (teaching learning proces) adalah suatu interaksi antara guru dan siswa dalam menciptakan aktivitas-aktivitas pendidikan yang dilaksanakan di sekolah. ${ }^{4}$

Definisi pembelajaran juga disamapaikan oleh Marshal yang dikutif dalam buku yang berjudul "model of teaching" mengklasifikasikan kegiatan pembelajaran menjadi empat bagian anatara laian

\footnotetext{
${ }^{2}$ Qamar Hamalik, Media pendidikan, (Bandung: PT Rosdakarya, 1982), 24.

3 Oeamar Hamalik, Proses Belajar Mengajar (Jakarta: PT Bumi Aksara, 2008), 27.

4 J.J. Hasbuan, Proses Belajar Mengajar (Bandung: PT Remaja Rosdakarya, 2009), 3.
} 
adalah sebagai berikut: yang pertama adalah proses penyampaian informasi. kedua, adanya perubahan perkembangan peribadi siswa. ketiga,terjadinya isteraksi sosialm dalam pembelajaran. Dan keempat membentuk dan merubah tingkah laku atau moral (pendidikan karakter).

Usman memberikan definisi mengenai pembelajaran adalah bahwa pembelajaran itu terjadi karena aktivitas dari seorang guru dan siswa yang berlangsung dalam kegiatan pendidikan untuk mencapai target yang diinginkan. ${ }^{5}$ Definisi pembelajaran yang diungkapkan oleh Benjamin S. Blom adalah bahwa dalam kegiatan belajar mengajar akan berpegang pada 3 domain/kawasan hasil belajar yaitu sebagai berikut cognitif, afektif dan psychomotor.

Bila dilihat dari beberapa pengertian/definisi yang disamapaikan oleh beberapa ahli tersebut, maka dapat diberikan pemahaman bahwa kegiatan belajar mengajar sebagai salah satu kegiatan yang di dalamnya terjadi interaksi antra seorag guru dan siswa. Jika terlihat adanya kegiatan pembelajaran maka secara tidak langsung akan terjadi proses belajar mengajar antara guru dan sisiwa dalam suatu keadaan. Dari kegiatan pembelajaran tersebut akan mendapatkan capaian-capaian tertentu yang menjadi tujuan/visi yang sudah menjadi target sebelumnya. Dengan demikian, kegiatan belajar mengajar agar bisa dilaksanakan dengan benar-benar efektif, efesien, secara sadar, dan terencana dengan konsisten baik perencaan pendidikan maupun perencanaan pembelajaran.

Pada era 1990-an, para reformer pendidikan berusaha mencari jawaban bagi dua pertanyaan fundamental yaitu seberapa baikkah para pelajar itu belajar di kelas? Dan seberapa efektifkah para guru itu mengajar di kelas? Penilaian kelas merespons secara langsung terhadap hal-hal mengenai pembelajaran yang lebih baik dan pengajaran yang lebih efektif. ${ }^{6}$

Pada masa globalisasi ini setiap sekolah seharusnya bisa menciptakan beragam inovasi pembelajaran, hal ini tentu yang akan menjadi pondasi berkulitas dan tidaknya sumber daya

\footnotetext{
${ }^{5}$ Moh. Uzer Usman, Menjadi Guru Profesional (Bandung: Remaja Rosdakarya, 2004), 4.

${ }^{6}$ Moh. Sholeh Hamid,.Standart Mutu Penilaian dalam Kelas (Jogjakarta: DIVA Pres, 2011), 55.
}

manusia. Seoranag guru dalam interaksi dengan siswa dituntut untuk menciptakan pembelajaran yang aktif, inovatif, kereatif dan menyenangkan, selain itu guru juga bisa memahami setiap kondisi dari para siswa, agar secara efektif para siswa bisa mengembangkan potensi yang dimilikinya. Semua itu akan berjalan dengan efektif dan efesien apabila dalam pengeloalaan kelas tentu menyesuiakan dengan beberapa kom ponen baik karakterik siswa maupun karakteristik mata pelajaran yang diajarkan, hal ini akan memeberikan kemudahan bagi seorang guru di dalam mengevaluasi dan menilai yang menyesuaikan dengan beberapa karakteristik dari masingmasing siswa di kelas. Agar pembelajaran menjadi efektif dan menyenangkan maka perlu bagi seorang guru untuk mengilplementasikan berbagai metode dan strategi di dalam pembelajaran dan juaga menata kembali ruang kelas, pengorganisasian kelas semua itu dilakakuan dengan memperhatikan beberapa karakteristik yang dimiliki oleh setiap siswa.

Menurut Hamzah mengenai tentang pengertian strategi pembelajaran bahwa seorang guru sebelum memulai pembelajaran hendakanya memiliki beberapa cara atau stretegi selama kegiatan belajar mengajar berlangsung. ${ }^{7}$

Dalam kegiatan belajar mengajar seorang guru harus bisa menetapakan berbagai kegiatan pembelajaran baik barupa stetegi pembelajaran, sarana prasarana baik berupa jenis media pembelajaran yang akan digunakan, juga beberapa metodologi yang akan diimplementasiakn ketika kegiatan belajar mengajar sedang berlangsung. Dengan demikian, siswa akan menjadi seperti apa yang diharapakan yang tentunya sesuai dengan tujuan pembelajaran, seperti adanya perubahan sikap dan pengalaman bagi sisa itu sendiri.

Oemar Hamalik mengklasifikasikan ada beberapa komponen penting yang sangat urgen di dalam kegiatan belajar mengajar di antaranya ialah menetapkan apa yang menjadi tujuan dalam pembelajaran di sekolah, pmemilihan materi pelajaran yang relevan dengan karakteristik siswa, pemilihan metode pembelajaran yang akan menjadi pendekatan di dalam kegiatan belajar mengajar, adanya para siswa/anak didik sebagai objek dalam kegiatan

\footnotetext{
7 Hamzah B. Uno, Model pembelajaran (Jakarta: PT Bumi Aksara, 2009), 3.
} 
belajar mengajar, peran guru dalam membong dan mengarahkan terhadap siswa sehingga terjadi kegiatan belajar mengajr yang harmonis, pemanfaatan media yang akan digunakan dalam kegiatan pembelajaran.

Dari bebrapa komponen penting tentang kegiatan belajar mengajar di atas tesebut bisa dijabarkan anatara lain adalah :

\section{Tujuan Pembelajaran}

Martinis Yamin memberikan pengertian tentang pentingnya penetapan tujuan pembelajaran adalah bahwa tujuan pembelajaran itu bagaiaman perencanaan baiak perencanaan dalam pembelajaran atau perencanaan dalam pendidikan dan hal itu merupakan seusuatu yang urgen yang perlu untuk dipertimbankan dalam penetepan tujuan pembelajaran ${ }^{8}$ karena yang perlu dipahami bahwa sertiap kegiatan belajar mengajar di sekolah secara umum dan di kelas secara khusus tentu akan merukjuk terhadap ketercapaiannya apa yang menjadi tujuan dari pembelajaran itu sendiri.

Penting untuk diperhatikan di dalam merumuskan agar ketercapaiannya tujuan dari pembelajaran baik secara sistematis dan secara kongkrit dan hal ini sebagai salah satu rekomendasi operasional dan pemilihan bahan pelajaran yang akan diajarkan kappa para siswa.

Hal-hal yang akan memberikan manfaat bagi sekolah dan dapat dihasilkan dari perencanaan pembelajaran yang bertujuan untuk kegiatan belajar mengajar dapat diklasifikasikan sebagai berikut ini:

b. Perlu adanya alokasi waktu yang bisa digunakan dengan sebaik mungkin oleh guru dan siswa.

c. Adanya relevansi antara materi yang akan diajarkan dengan penggunaan alokasi waktu.

d. Adanya penetapan materi yang disingkronkan dengan alokasi waktu yang akan digunakan dalam kegiatan pembelajaran.

e. Adanya urutan yang sistematis terkait penetaan materi yang akan diajarkan oleh guru ke siswa.

f. Adanya persiapan yang secara matang dari guru dalam pemilihan dan penetapan terkait strategi

\footnotetext{
${ }^{8}$ Martinis Yamin, Manejemen Pembelajaran Kelas (Jakarta: Gaung Persada, 2009), 130.
}

yang akan digunakan dlam kegiatan belajar mengajar.

g. Adanya kesiapan dari guru dalam kesiapan penggunaan media pembelajaran dan materi pelajaran.

h. Adanya jaminan dari guru dengan dibuktikan keberhailan dari siswa dalam mendapatkan pretasi yang baik.

\section{Materi Pelajaran}

Untuk menentukan materi yang akan diajarkan kapada para siswa maka yang perlu diperhatikan adalah perumusan materi setelah tujuan pembelajaran terlebih dahulu ditetapkan. Karena sebagaimana yang disampaikan oleh ahli bahwa materi pelajaran adalah isi atau konten yang diberikan oleh guru kepada siswa ketika sedang dalam kegiatan belajar mengajar. ${ }^{9}$ Dengan melalui kegiatan belajar mengajar maka secara langsung akan mengantarkan siswa terhdapa tujuan pembelajaran yang sudah ditetapkan.

Beberapa keriteria yang perlu untuk disiapkan di dalam menentukan matari pelajaran yang akan di berikan kepada para siswa antara lain adalah :

a. Materi yang akan diajarkan bagi siswa seharusnya menyesuaikan dengan ketercapaiaannya tujuan pembelajaran.

b. Materi yang menjadi program smester yang suadah dituangkan dalam bentuk sialbus jangan hanya menonton pada konseptual saja tap lebih kapada peraktek.

c. Pada pokok bahasan dan pada sub bahasan materi pelajaran harus berurutan dan adanya relevansi.

d. Matari yang diajarkan agar lebih komprehensip maka harus ada kesesuaian dan berkolerasi antara materi yang satu dengan materi yang lainnya.

e. Agar siswa lebih mudah memahami materi yang diajarkan oleh guru, maka guru harus bisa memilah dan meilih dari Materi yang mudah dipahami sampai menuju materi yang sulit dipahami.

\footnotetext{
${ }^{9}$ Nana Sudjana, Dasar-Dasar Proses Belajar Mengajar (Bandung: Sinar Biru Grafindo), 67.
} 
f. Materi yang akan diajarkan harus mengandung materi yang bersifat faktual dan bersifat konseptual.

Penting bagi seoarang guru agar bisa melakukan penseleksian terhadap materi yang akan diajarkan kepada siswa, mengingat tidak semua siswa memiliki buku referensi. Dengan demikian, ketika materi pelajaran yang diajarkan kepada siswa sudah sesuai dengan apa yang menjadi tujuan dalam pembelajaran, dan juga adanya kesinambungan, dan juga materi tersebut tersusun secara rapi dan baik, maka semua itu akan sangat mudah dalam memberikan peluang terhadap ketercapaian hasil belajar siswa yang sangat optimal.

\section{Metode Pembelajaran}

Untuk meningkatkan kualitas kegiatan belajar mengajar agar lebih efekti dan efesien dan sesuai dengan apa yang menjadi tujuan yang sudah ditetapkan, maka sangat penting bagi guru untuk menggunkan strategi pembelajaran dan juga metode pembelajaran. Martinis Yamin memberikan definisi tentang metode pembelajaran adalah sebagai salah satu upaya pencapaian tujuan secara efektif dan efesien maka perlu bagi guru dalam kekgiatan belajar mengajar memakai metode pembelajaran ${ }^{10}$

Bagi seorang guru sangat dianjurkan untuk banyak mngikuti workshop guna bisa menyerap beberapa metode dan model-model pembelajaran yang efektif dan inovatif untuk di implementasikan dalam kegiatan belajar mengajar di kelas, metode pembelajaran yang dipilih adalah metode pembelajaran yang paling terbaru mengingat metode pembelajaran banyak mengalami dinamisasi tentu hal ini diperlukan kepekaan dari seorang guru dalam merespon setiap perkembangan yang di alami oleh siswa di sekolah. ${ }^{11}$

Implemetasi berbagai metode pembelajaran merupakan salah satu komponen penting untuk meningkatkan kualitas kegiatan belajar mengajar di kelas. Oleh karena itu yang perlu diperhatikan oleh guru bisa memilah dan memilih metode pembelajaran yang ada relevansinya dengan mataeri pelajaran, karena tidak semua metode pembelajaran cocok

\footnotetext{
${ }^{10}$ Martinis Yamin, Manejemen Pembelajaran Kelas (Jakarta : Gaung Persada, Cet. 1, 2009), 148.

${ }^{11}$ Jamal Ma'mur Asmani, Tips Menjadi Guru Insfiratif, Kreatif dan Inovatif (Jogjakarta : DIVA Press, 2009), 138.
}

dengan satu materi saja tapi bisa menyeseuaikan dengan karakteristik matiri pelajaran yang lainnya.

Guna untuk mencapai tujuan pembelajaran, maka bagi seorang guru bisa memilih bebrapa metode pembelajaran untuk diaplikasikan dalam kegiatan belajar mengajar. Ada beberapa kalsifikasi metode pembelajaran anatara lain sebagai berikut:

a. Meode ceramah, metode ini adalah metode yang digunakan dalam kegiatan belajar mengajar melaui penjelsan secara langsung oleh guru kepada siswa. ${ }^{12}$

b. Metode tanya jawab, metode ini adalah metode dialogis antara guru dengan siswa, hal ini bisa terjadi ketika seorang guru menjelaskan materi pelajaran secara mendalam lalu kemudian memberikan kesempatan kepada siswa untuk bertanya tentang materi pelajaran yang belum dipahami oleh siswa.

c. Metode diskusi, metode ini adalah metode active learning, karana dengan adanya diskusi tentang materi pelajaran yang diberikan oleh guru siswa yang satu dengan siswa yang lain bisa mengemukakan argumentasinya dan pada akhirnaya akan menemukan penyelesaian dari masalah tersebut dan akan menjadi keputusan yang bisa disepakati sesame siswa.

d. Metode kelompok, metode ini sangat efektif karena adanya keterlibatan secara bersama-sama antar kelompok untuk menyelesaikan apa yang menjadi tugas dan tanggunjabnya.

e. Metode demonstrasi, metode ini sangat eektif sekali kerena dalam implemetasi penerapan metode ini siswa mencari permasalahan yang ada hubungannya dengan materi pelajaran lalu kemudian siswa berusaha untuk menemukan sendiri jawaban atas permasalahan yang yang dipilih tesebut.

f. Metode Problem Solving, metode ini lebih kepada bagaimana siswa bisa berikir aktif dan konstruktif untuk bisa memecahakan masalah dalam pelajaran. Metode ini lebih banyak digunakan dipergurun tinggi mengingat di

\footnotetext{
${ }^{12}$ Martinis Yamin, Manejemen Pembelajaran Kelas (Jakarta: Gaung Persada, 2009), 149.
} 
perguruan tinggi melibatkan mahasiswa yang notabeninya berfikir kritis dan konstruktif dalam menghadapi berbagai permasalahan yang dihadapinya.

Dari bebrapa metode tersebut, tentu sangat penting bagi seorang guru untuk bisa mengaplikasikan metode tersebut dengan memperhatikan beberapa karakteristik baiak karakteristik siswa, karakteristik materi pelajaran dan juga karakteristik media yang digunakan dengan memperhatikan beberapa karakteristik tesebut akan menjadikan pembelajaran yang aktif, inovatif dan mnyenangkan.

\section{Peserta Didik}

Dalam aktivitas kegiatan belajar mengajar ada kertelibatan secara langsung anatara guru dengan siswa hal ini yang disebut oleh sebgaian orang dengan istilah interakasi edukatif guru dan sisiwa. Dalam interaksi kegitan belajar mengajar siswa merupakan salah satu subjek utama dalam kegiatan proses belajar mengajar. Siswa merupakan salah satu komponen penting dalam aktivitas pembelajaran, selain itu juga yang merupakan komponen pentingnadalah adanya guru, visi mdan misi, strategi dan mmetode pembelajaran. ${ }^{13}$

Keterlibatan secara langsung siswa di dalam kelas marupakan salah satu komponen penting. Secara subtantib sisa tersebut bisa menjadi salah satu factor yang sangat menentukan dalam kegiatan belajar mengajar. Disadari atau tidak tanpa keterlibatan siswa secara langsung maka sudah pasto tidak akan terjadi interaksi pemblajaran di kelas. Dengan demikian, yang perlu menjadi pusat perhatian dan menjadi prioritas adalah tentang keberadaan dan perkembangan intelektualnya, setalah kondisi siswa sudah menjadi perhatian, lalu kemudian bisa memikirkan komponenkomponen yang lainnya sebagai pendukung seperti adanya materi peelajaran, metode pelajaran, maupun sarana perasarana berupa media, gedung dan lain sebagainya yang sangat mendukung dalam kegiatan belajar mengajar.

5. Guru

Kehadiran guru dalam kegiatan belajar mengajar merupakan salah satu komponen yang

${ }^{13}$ Oeamar Hamalik, Proses Belajar Mengajar (Jakarta: PT. Bhumi Aksara, 2004), 99. urgen sekali, karena guru tidak hanya mengajar tapi juga mendidik. Bila dilihat dari tugas guru adalah sangat kompleks sekali yaitu guru sebagai pengajar, pendidik, pelatih, pengarah, pembimbing, penilai dan mengevaluasi. Dengan demikian, kehadiran guru dalam proses kegiatan pembelajaran sangat diperhitungkan, selain tugas-tugas guru yang disebutkan di atas guru juga menyandang banyak peran yang harus diimplemtasikan dalam kegitan belajar, seperti guru sebagai mediator, fasilitator, inspirator dan lain sebagainya. Seorang guru adalah orang yang mengajarkan ilmu untuk para siswa, selain mengajarkan tentang pengetahuan/ilmu guru juga bisa menciptakan pengembangan terhadap siswa baik pengembangan dalam masalah pemahaman, maupun pngembangan terhadap sumber daya siwsa itu sendiri.

Tugas dari seorang guru tidak hanya berperan dalam mentrasfer pengetahuan saja, akan tetapi tugas dari seorang guru juga berperan sebagai pendidik dan juga memberikan bimbingan baik secara rohani maupun secara jasmani. Sepintas kalau dilihat memang ada perbedaan yang subtantif antara guru sebagai pengajar dengan guru sebgai pendidik. Dalam istilah pendidika Islam dikenal dengan istilah Attarbiyah, Atta'lim, dan Atta'dib, hal ini sangat relevan dengan teori taksonomi Blom tentang domain hasil belajar yaitu kognitif, afektif dan psikomotorik.

Dari penjelasan di atas tentang guru sebagai salah satu komponen penting dalam kegiatan belajar mengajar, hal ini sejalan dengan pendapat Adam dan Decey bahwa ada beberapa tugas penting dari seorang guru yaitu; guru sebagai pendidik, guru sebgai pengajar, guru sebagai pembim bing, guru sebagi perencana, guru sebagai pangatur lingkungan, guru sebagai partisipan, guru sebagai konselordan guru sebagai motivator. ${ }^{14}$

\section{Pembelajaran PAI di Sekolah}

Pembelajaran PAI di sekolah sangat penting untuk diajarkan kapada siswa baik di tingkat sekolah TK, SD, SMP, SMA dan Perguruan Tinngi. Oleh karena itu bahwa PAI salah satu istilah yang mengarah pada pengertian secara operasional dalam rangka

\footnotetext{
${ }^{14}$ Moh. Uzer Usman, Menjadi Guru Profesional (Bandung: Remaja Rosdakarya, 2004), 9.
} 
untuk memasukkan ajaran-ajaran yang ada dalam agama Islam tersebut selain tiu PAI adalah bagian dari sub sistem pendidikan Islam. Secara mendasar bahawa pendidikan agama Islam merupakan salah satu implementasi pendidikan agama Islam yang harus diajarkan di sekolah. Pembelajaran PAI itu bisa dalam bentuk aktivitas keguiatan belajar mengajar atau kegiatan kegiatan yang lain yang positif yang sesuai dengan syariah Islam dengan tujuan untuk mecapai target dalam tujuan pendidikan agama Islam tersebut.

Dalam pendidikan Islam yang menjadi prinsip adalah pengesaan kepada Allah SW'T. yaitu dengn prinsip tauhid, prinsip tauhid ini berpandangan bahwa segalanya berasal dan semuanya juga berakhir. Prinsip tauhid ini sudah menjadi prinsip yang sangat meninspirasi sekali dalam mengembangkan suatu teori tentang pelakasnaan pendidikan Islam baika secara nonformal, formal dan informal. Pendidikan Islam secara nonformal adalah pendidikan yang dilaksnakan dalam masyarakat setempat berupa pengajian dan lainlain, pendidikan informal pendidikan di aplikasikan dalam keluarga sedangkan pendidikan formal pendidikan Islam yang diajarkan dalam lembaga pendidikan baik di mulai dari TK sampai perguruan tinggi.

Halim Soebahar memberikan penjelasan tentang pentingnya untuk memehami terhadap Pendidikan Islam, sehingga pendidikan Islam dapat diklasifikasikan menjadi empat pengertian. Pertama, pengertian pendidikan Islam dalam pengertian materi, yaitu materi PAI yang wajib diajarkan dan berikan pada semua jenis, dan jenjang pendidikan baik dalam sekolah ataupun madrasah dari tingkat TK sampai tingkat perguruan tinggi. Kedua, pendidikan Islam dalam pengertian institusi; pengertian ini lebih merujuk kepada tempat yang identtik dengan lembaga pendidikan Islam seperti pondok pesantren lembaga keagamaan lainnya. Ketiga, pendidikan Islam dalam pengertian budaya dan nili-nilai, pengertian ini mengandung bahwa pendidikan itu agar bisa mengandung pendidikan karakter dan moral, mengingat pentingnya moral dan karakter dalam kehidupan berbangsa dan beragama, oleh karan itu dirasa penting penddikan Islam itu sendiri menjadi pilar untuk dijadikan pijakan dalam berakhlakul karimah yang baik yang pada akhirnya akan terbentuk budaya yang relegius. Keempat, pendidikan Islam dalam pengertian pendidikan yang islami, perlu dipahami bahwa pendidikan yang Islami ini merupakan salah satu unsur terpenting bagi setiap aktivitas keagamaan tidak keluar dari koridur hukum yang sudah menjadi landasan dan ketentuan yang harus dilaksanakan oleh setiap umat beragma. Oleh karena itu, pendidikan yang islami dalam aplikasinya tidak menyimpang dari apa yang menjadi ajaran dari Islam itu sendiri. ${ }^{15}$

\section{Pemanfaatan Media Pembelajaran}

Ada beberapa istilah yang digunakan dalam memehami media, sehingga muncul beberapa bahasa dengan istilah yang berbeda akan tetapi secara subtansi memiliki makna yang sama. Bahasa latin menggunakan istilah medius yang bermkna perantara atau pengantar sedangkan dalam bahasa Arab menggunakan istilah (وسائل) yang memiliki pengertian perantara atau pengantar informasi dari oaring keorang. ${ }^{16}$

Dari pengertian secara istilah tersebut, maka para ahli pun memberikan pengertian sesuai dengan kapasitas dan kapabiltas dari masing-masing apara ahli sehingga mengemukakan pendapatnnya berikut ini:

1. Pengertian media menurut Santoso bahwa media adalah segalah sesuatu yang digunakan oleh seseorang untuk menyampaikan sebuah ide atau gagasan sehingga ide atau gagasan iitu bisa diterima dengan baik oleh penerima pesan tersebut.

2. Pengertian media menurut AECT bahwa media adalah segalah sesuatu yang bsia dipakai untuk memberikan berita, informasi dan pesan.

3. Pengertian media menurut NEA bahwa media adalah salah satu alat yang bisa dijadikan alat komunikasi baik dalam bentuk audio, visual dan dalam bentuk cetak.

4. Pengertian media menurut Brigh, bahwa media itu adalah suatu alat yang digunakan dengan tujuan memberikan stimulasi atau rangsangan pada setiap orang yang menerima pesan.

\footnotetext{
${ }^{15}$ Abd. Halim Soebahar, Kebijakan Pendidikan Islam (Jember: Pena Salsabila, 2012), 1.

16 Azhar Arsyad, Media Pengajaran (Jakarta : PT Raja Grafindo Persada, 2000), 3.
} 
Pengertian pembelajaran yang diambilkan dari bahasa Inggris dengan istilah instruction memiliki makna dan pengertian yang lebih luas cakupannya dari pada istilah pengajaran. Pengajaran dimaknai dengan adanya interaksi antara guru dan siswa di dalam kelas secara formal bagitu pula istilah pembelajaran lebih mengarah kepada kegiatan belajar mengajar yang tanpa harus dihadiri oleh seorang guru secara fisik. Dengan demikian, yang perlu dipahami dalam konteks pembelajaran lebih ditekankan adanya aktivitas kegiatan belajar mengajar di sekolah. ${ }^{17}$

Secara terpisah pengertian media dan pembelajaran yang sudah dijelaskan di atas, maka dapat ditarik dipahami bahwa pengertian media pembelajaran adalah merupakan salah satu yang dipakai dalam mengirimkan/menyalurka pesan serta memberikan stimulasi terhadap perhatian, pikiran, perasaan, dan kemauan para siswa dalam kegiatan pembelajaran, oleh karena itu kehadiran media pembelajaran akan memberikan pengaruh dan dampak yang sangat mennjol akan terjadinya aktivitas kegiatan pembelajaran secara efekti dan efesien. Pemanfaatan penggunaan media pembelajaran dengan memperhatikan karakteristik dari media tersebut secara kreatif akan membantu mempermudah memahmi materi pelajaran yang diajarkan oleh guru pada siswa dan juga menghindari adanya verbalisme pada diri siswa.

\section{Klasifikasi Media Pembelajaran}

Ada beranekaragam media yang dapat digunakan dalam kegiatan belajar, akan tetapi bila dilihat dari segi karakteristik media tersebut, maka media pembelajaran bisa diklasifikasikan menjadi tiga macama yaitu adalakanya media hanya bisa dilihat (visual), ada juga media yang hanya bisa didengar (audio) dan ada pula media yang bisa dilihat dan juga bisa didengar (audio visual). ${ }^{18}$

Sedangkan Media pembelajaran bila dilihat dari jenisnya, daya liputnya dan dari bahan serta cara penggunaannya. Oemar Hamalik mengklasifikasikan media pembelajaran itu menjadi empat macam, yaitu :

\footnotetext{
${ }^{17}$ Oemar Hamalik, Kurikulum dan Pembelajaran (Jakarta : PT Bumi Aksara, 2009), 55.

${ }^{18}$ Moh. Uzer Usman, Menjadi Guru Profesional (Bandung: Remaja Rosdakarya, 2004), 86
}

a. Media Visual adalah merupakan salah satu media yang dapat dilihat tetapi tidak bisa didengar, ada beberapa contoh media visual tersebut yang bisa digunakan dalam kegiatan pemelajaran antara lain seperti peta, globe, poster, grafik, papan tulis, buku, bulletin board, transparansi, micro projection.

b. Media Audio, media ini hanya bisa didengar akan tetapi tidak bisa dilihat, penggunaan media ini dalam kegiatan pembelajaran hanya menampilakn suara saja sepeti contoh rekaman, radio, tape recoder dan phonographrcoed.

c. Media audio visual, media ini menggabungkan dari dua media sekaligus yaitu audio dan visual. Media ini dalam penggunaannya dalam kegiatan belajar yang paling mudah dicerna oleh siswa karena tidak hanya menampilkan ngambar saja melainkan njuga menampilkan susra seperti contoh video, televisi, dan film.

Dari berbagai media intruksional tersebut, kesemuanya dapat menunjang dalam proses belajar mengajar, akan tetapi perlu diingat bahwa pemakaian media tersebut tidak hanya melihat pada kecanggihannya saja, namun yang lebih penting (Urgen) adalah bagaiamana dengan kehadiran media tersebut mampu memeberikan kemudahan bagi para siswa dan juga harus menyesuaikan dengan apa yang menjadi tujuan dari kegiatan pembelajaran. Dengan demikian, yang perlu diperhatikan bagaimana penggunaan media disesuaikan dengan apa yang menjadi tujuan dari pembelajaran, bahan materi pelajaran dan setelah ituguru bisa menentukan media amana yang akan digunakan tentu disesuaikan dengan kemampuan guru dalam mengoperasikan media tersebut.

\section{Peranan Media pembelajaran}

Peranan media pembelajaran dalam kegiatan belajar mengajar dapat diklasifikasikan dengan beberapa peranan antara lain adalah sebagai berikut:

a. Secara edukatif, media yang digunkan dalam kegiatan pembelajaran akan meilki dampak yang positif karena dengan adanya media tersebut bisa memberikan penaruh dan dapat memberikan nilia-nilai yang positif dalam pendidikan. Oleh karena itu, penggunaan media yang baik akan memberikan distimulasi terhadap siswa di dalam 
mengikuti pelajaran dan mempermudah siswa dalam mengerti terhadapa materi yang diajarkan oleh guru.

b. Secara sosial, kehadiran media bisa memberikan pengaruh yang besar bagi siswa dengan terciptanya kepribadian siswa yang lebih posistif secara sosial, mengingat manfaat dan fungsi media pembelajaran yang digunakan sebagai alat bantu, oleh karena itu adanya media itu merupakan salah satu tahapan terhadap sikap sosial siswa yang sudah teruji dengan kehadiran media sebagai alat bantu dalam kegiatan belajar..

c. Secara ekonomis, kehadiran media sangatlah membantu terhadap siwsa dan bisa dinikmati selamanya oleh siswa. Oleh karena itu, secara ekonomi siapapun boleh memanfatkan media disesuaikan dengan kebutuhannya. Media bisa mengurangi beban yang sangat berat terhadap tenaga manusia, kerana ketika ada pelajaranpelajaran yang khusus sudah tidak perlu lagi di menyajikan materi pelajaran.

d. Secara politis, kehadiran media secara politik adalah sebagai salah satu mikanisme yang tidak ada perbedaan satu sama lain yaitu sumber pelajaran yang berawal dari pusat akan sampai ke daerah-daerah yang lainnya. Setiap lembaga pendidikan/sekolah yang satu dengan sekolah yang lainnya tidak akan ada perbedaan antara baik sekolah itu ada di daerah pusat dengan ataupunsekolah itu berda ditempat yang npaling terpencil sekalipun. Ini sebagai indikasi bahwah manfaat dan fungsi media sudah sangat peraktis.

e. Secara Seni, media ini bisa membuat kita kaya akan budaya, mengingat media ini bukan hanya dikenal oleh satu klompok orang saja, akan tetapi hamper semua kelompok bisa mengetahui bergam budaya hasil seni dari manusia. Dengan demikian, kehadiran media sebagai seni ini dengan pemanfaatn penggunaan media secara tidak langsung akan memberikan dampak pengetahuan yang posistif bahkan memberikan wawasan yang mendalam bagi siswa tersebut.

Dari beberapa peranan penting media dalam pembelajaran, yang mana media itu sebagai alat bantu yang digunakan dalam kegiatan belajar dan akan membaerikan manfaat dan fungsi bila penggunaan media dilakukan dengan benar-benar sesuai dengan karakteristik materi pelajaran, karakteriustik siswa dan karakteristik sekolah (lingkungan).

Paparan diatas mengenai peranan penting media pembelajaran karena dalam kegiatan pembelajaran akan memberikan dampak yang positif bagi perkembangan dan wawasan siswa sehingaga akan menjadikan siswa berprestasi dalam segala bidang materi pelajaran yang dipelajari di sekolah.

\section{Karakteristik Media Pembelajaran}

Karakteristik media pembelajaran yang digunakan dalam kegiatan belajar harus benarbenar diperhatikan oleh seorang guru guna untuk menyesuaikan tujuan pembelajaran, materi pelajaran dan kebutuhan siswa itu sendiri. Karakteristik media pembelajaran yang digunakan dalam kegiatan belajar dapat diklasifikasikan menjadi tiga karakteristik yaitu sebagai berikut:

a. Karakteristik media fiksatif property, karakteristik media ini mempunyai kemampuan untuk menampilkan perekaman, penyimpanan, mengembangkan dan merekonstruksi suatu kejadian atau objek tertentu. Dengan demikian, ciri media fiksatif ini sangat memungkinkan untuk merekam kejadian yang pada saat waktu tertentu dan bisa diganti atau dirubah kapanpun tanpa adanya mengenal waktu dan tempat. ${ }^{19}$ Contoh dari ciri media fiksatif ini seperti; film, audio tape, video tape, disket dan foto.

b. Karakteristk media Manipulatif property, karakteristik media ini dalam kegiatan belajar mengajar akan sangat membantu para guru sesuai dengan kebutuhan guru tentu harus disesuaikan dengan tujuan pembelajaran, materi pelajaran dan kemamampuan siswa. Ciri media manipulatif ini bisa merubah tampilan suatu objek seuai dengan keinginan, sehingga durasi waktu bisa diatur dengan disesuaikan dengan kebutuhan bisa mempercepat dan bisa memperlambat tayangan video hasil rekaman. ${ }^{20}$

c. Karakteristik media Distrubutif property),

\footnotetext{
${ }^{19}$ Azhar Arsyad, Media Pengajaran (Jakarta: PT Raja Grafindo Persada, 2000), 12.

${ }^{20}$ Azhar Arsyad, Media Pengajaran (Jakarta: PT Raja Grafindo Persada, 2000), 13.
} 
karakterstik media distributif ini sangat membatu guru dalam kegiatan pembelajaran mengingat ciri media tesebut bisa menampilkan suatu peristiawa atau objek tertentu melalui ruang dan tempat. Dengan demikian, media ini bisa menampilkan suatu objek secara bersamaan sehingga dari sejumlah besar siswa bisa menikmati tampilan ntersebut sesuai dengan pengalaman dan stimulus tentang kejadian objek tersebut. Oleh karena itu, setiap peristiwa atau objek yang direkam dalam bentuk media apapun, maka media tersebut dapat dtransformasikan dalam bermacam bentuk dan siap ditampilkan secara berulang-ulang sesuai dengan kebutuhan.

Dari penjelesan di atas tentang karakteristik media pembelajaran yang dipergunakan dalam kegiatan belajar mengajar. Sangat penting untuk diperhatikan oleh segenap dewan guru untuk memilah dan meilih media mana yang sesuai dengan karakteristik yang nantinya kan digunakan dalam kegiatan pembelajaran agar kegitam pembelaaran itu berjalan dengan efektif dan efesien dan bisa meningkatkan hasil belajar siswa.

\section{Kriteria dalam Pemilihan Media Pembelajaran}

Dalam Setiap proses kegiatan pembelajaran akan ada beberapa indikasi adanya komponenkomponen dalam pembelajaran seperti; tujuan pembelajaran, bahan materi pelajaran, metode pelajaran, alat serta evaluasi dalam pembelajaran. Komponen alat dalam artian media pembelajaran (alat peraga) merupakan salah satu komponen penting yang tidak bisa di hilangkan dari pada komponen yang lainnya. untuk ketercapaian tujuan pebelajaran, maka secara tidak langsung peranan alat peraga (media pembelajaran) menjadi peranan yang sangat penting, karena dengan adanya alat peraga ini maka dengan sangat mudah isi bahan pelajaran di pahami oleh para siswa. Dalam aktivitas pembelajaran media itu pembelajaran di pergunakan dengan tujuan agar bisa membantu para guru lebih efektif dan efesien dalam kegiatan belajar ${ }^{21}$

Agar bisa mencapai tujuan pembelajaran tersebut, maka guru sehrusnya bisa danmampu dalam memilih dan meilah media mana yang tepat

\footnotetext{
${ }^{21}$ Nana Sudjana, Dasar-Dasar Proses Belajar Mengajar (Bandung: Sinar Baru Grafindo), 99.
}

dimanfaatkan dalam aktivitas pembelajaran, ada beberapa kriteria dan karakteristik media pembelajaran yang efektif dan efesien antara lain adalah :

a. Adanya relevansi dengan tujuan pembelajaran. Pemanfaatan penggunaan media pembelajaran harus benar-benar ada kesesuaian antara yang dipilih dengan catatan harus berpijak pada dasar-dasar dari tujuan pendidikan yang telah ditetapkan sebelumnya. Salah satu dari tujuan pendidikan adanya komponen/ unsur pemahaman, komponenunsur aplikasi, komponen/unsur analisis, dan komponen unsur sintesis yang lebih mungkinkan untuk digunakan media pembelajaran tersebut dalam kegiatan pembelajaran. Dalam artian bahwa dalam penggunaan media pembelajaran tersebut harus menyesuaikan dengan beberapa tujuan yang telah ditetapkan sebelumnya dan sekiranya dapat mendukung secara efektif dan efisien terhadap tercapainya tujuan pembelajaran tersebut.

b. Adanya relevansi terhadap isi materi pelajaran. Relevansi media terhadap isi materi pelajaran yang akan digunakan dalam pelaksanaan kegaitan pembelajaran tesebut dengan bahan materi pelajaran yang akan di sampaikan sehingga dengan dioperasikannya media tersebut tentu harus ada relevansinya dengan bahan materi yang akan diajarkan., maka akan dapat mendukung terhadap materi pelajaran tersebut. Dalam artian bahwa bahan isi pelajaran yang notabeni berbentuk konsep, berbentuk fakta, dan berbentuk prinsip maka dapat dengan mudah di fahami oleh siswa.

c. Ketersediaannya Media di Sekolah. Seorang guru di dalam mempergunakan berbagai media pembelajaran hendaknya mencari media yang tidak sulit untuk memperolehnya. Paling tidak media pembelajaran tersebut dapat di buat dengan mudah oleh guru tersebut pada saat guru sedang mengajar. Yang terpenting media pembelajaran tersebut bisa mendukung terhadap materi pelajaran sehingga siswa dengan mudah memahaminya. Apalah artinya media pembelajaran yang mahal harganya, akan tetapi sama sekali tidak mendukung terhadap materi pelajaran yang akan di sampaikan. 
d. Guru harus trampil dalam menggunakan media. Maksudnya bahwa dengan bebrapa jenis media pembelajaran yang akan digunakan utamanya adalah bagaimana seorang guru bisa mengoperasikan media dalam kegiatan belajar mengajar di kelas. Dalam artian bahwa seorang guru yang berkeinginan mengunakan media pembelajaran maka terlebih dahulu guru tersebut dapat bisa mengoperasikannya. Oleh karena itu, dampak dari penggunaan media itu bukan terletak pada sebuah nilai dan manfaat dari media tersebut, akan tetapi bagaimana seorang guru mampu di dalam mengoperasikan media pembelajaran tersebut dengan efektif dan efesien pada saat kegiatan belajar mengajar di kelas sedang berlangsung. Misalnya dengan adanya OHP (Over Head Projector), tidak ada artinya sama sekali bilamana seorang guru tersebut tidak memiliki keterampilan dalam mengoperasikannya dalam proses belajar mengajar untuk mepertinggi kwalitas pembelajaran.

e. Adanya waktu yang cukup dalam penggunaan media. Seorang guru harus pandai-pandai membagi waktu dalam menggunakan media pembelajaran tersebut. Sehingga siswa dapat merasakan manfaat dengan digunakannya media dalam kegiatan pembelajaran. Oleh karena itu, kehadiran media pembelajaran akan sangat bermanfaat bagi siswa selama pelajaran berlangsung. Yang pada akhirnya tidak ada kesan bahwa ada sebagian siswa belum bisa memanfaatkan media pengajaran karena jam pelajaran telah habis.

f. Sesuai dengan cara berfikir siswa. Maksudnya bahwa media yang digunakan baik dalam pendidikan maupun dalam pembelajaran harus relevan dengan kemapuaan berfikir siswa oleh karena itu, penyampaian materi pelajaran akan sangat mudah bisa dimengerti oleh para siswa. Salah satu contoh dalam penyajian gambar grafik yang di dalamnya berisi tentang data dan angka yang melibatkan anak SD, tentu hal itu tidak ada manfaatnya bagi anak SD karena taraf berfikirnya tidak sesuai dengan apa yang dilihatnya. Bagitu juga dengan tampilan diagram yang berisi tentang penjelasan alur hubungan antara satu prinsip atau konsep tentu hal itu dapat dilakukan oleh para siswa yang cara berfikirnya sudah mempunyai taraf berikir yang lebih baik. Dengan demikian haruslah ada kesesuaian dalam penggunaan media pembelajaran dengan tingkat berfikir siswa.

Berangkat dari penjelasan tentang kriteria pengguaan media pembelajaran tersebut di atas, maka harus ada kesesuaian antara penggunaan media pembelajaran tersebut dengan kesesuaian antara penggunaan media dengan materi dan tingkat berfikir siswa yang diajari, oleh karena itu, maka perlu kiranya pembagian media yang sekiraya ada kesesuaian digunakan pada siswa SMP ataupun sederajat. Contoh-contoh media yang cocok digunakan pada usia tersebut antara lain yaitu : grafik, sketsa, diagram, pita kaset, radio, laboratorium bahasa. Peta, papan buletin, mikroskop, OHP, dan Televisi serta komputer.

\section{Fungsi Media Pembelajaran}

Fungsi dan manfaat media pembelajaran dalam kegiatan belajar mengajar sangatlah diperlukan keberadaannya sebagai sarana dalam penerimaan materi pelajaran yang dirasa sulit untuk menerima materi tersebut apabila tanpa adanya alat atau media pembelajaran. Dengan demikian, media yang digunakan dalam kegiatan belajar mengajar sangat berperan dan memberikan dampak yang positif terhadap peningkatan aktivitas belajar siswa di kelas.

Kehadiran media diharapkan bisa memberikan distimulasi bagi siswa dalam kegiatan belajar sehingga pada ahirnya nanti memberikan dampak dalam hal peningkatan hasil belajar. Ada beberapa manfaat dan fungsi dari media pembelajaran yang digunakan dalam kegitan belajar dan mengajar adalah sebagai berikut :

a. Adanya media sangat menarik bagi siswa dan akan menjadikan siswa lebih termotivasi dalam belajar.

b. Materi pelajaran nyang akan diajarkan kepada siswa akan sangat mudah bisa dimengerti yang pada ahirnya nanti menjadikan siswa lebih banyak mengauasi terhadap tujuan pembelajaran dengan lebih baik. 
c. Adanya media berfungsi memudahkan guru dalam memilah dan memilih dalam berbagai metode dan strategi pembelajaran sehingga tidak aka nada rasa embosankan terhadap siswa.

d. Kegiatan belajar akan semakin aktif dan efektif, karena para siswa tidak hanya mendengarkan uraian guru, di samping itu pula siswa bisa melakukan kegiatan yang lainnya misalnya dengan cara mengamati, dan dengan mendemonstrasikan terhadap materi pelajaran yang dipahaminya. ${ }^{22}$

Dari beberapa fungsi dan manfaat media pembelajaran yang disebutkan di atas, maka dapat dipastikan kegiatan belajar mengajar akan berjalan dengan efektif dan efesien. Oleh karena itu akan berdampak poositif terhadap peningkatan hasil belajar siswa.

\section{SIMPULAN}

Dari beberapa penjelasan di atas dapat ditarik kesimpulan bahwa dalam kegiatan belajar mengajar kehadiran media mempunyai arti dan peran yang sangat penting (urgen), karena media sebagai sarana untuk mempermudah mempelajari segalah bentuk pelajaran dan di samping itu pula kehadiran media bisa mmeberikan dampak yang positif dalam peningkatan kualiatas belajar mengajar di sekolah. Disadari ataupun tidak disadari ternyata kehadiran media dalam kegiatan belajar mengajar berdampak yang signifikan bahkan bisa membantu para dewan guru dalam memberikan pesan-pesan isi materi pelajaran terhadap siswa. Ketika mengajar tanpa adanya media, maka secara tidak langsung akan menyulitkan guru dalam menyampaikan isi pesan dari materi pelajaran dan juga siswa merasa kesulitan di dalam memahami materi pelajaran yang diberikan guru.

Ada beberapa media pembelajaran yang bisa diaplikasikan dan diimplementasikan untuk menunjang keefektifan dan peningkatan kualitas pembelajaran PAI di sekolah antara lain media visual, media ini adalah bisa dilihat sepeti adanya papan tulis, buku ajar, grafik, poster, peta dan globe. Selanjutnya media audio, media ini tidak bisa dilihat melainkan hanya bisa didengar seperti;

${ }^{22}$ Nana Sudjana, Dasar-Dasar Proses Belajar Mengajar (Bandung: Sinar Baru Grafindo), 2. tape recorder, radio, phonograph record, rekaman. Terakhir adalah media audio visual, media ini bisa dilihat dan bisa didengar seperi; vidio, laboratorium bahasa, kmputer, dan televisi. Dari berbagai media intruksional tersebut, kesemuanya dapat menunjang dalam kegiatan belajar mengajar, agar pemanfaatan penggunaan media pembelajaran lebih eektif, maka yang perlu diperhatikan oleh setiap guru adalah bahwa pemakaian media tersebut tidak hanya melihat pada kecanggihannya saja, namun yang lebih penting adalah kualitas dalam kegiatan belajar mengajar harus relevan dengan apa yang menjadi tujuan yang ingin dicapai dengan maksimal. Dengan demikian, pemanfaatan penggunaan media pembelajaran yang efektif dan efesien tentunya sangat ditentukan dengan tujuan pembelajaran, materi pelajaran kemudian memproleh media yang dibutuhkan yang sesuai dan kemampuan dalam menggunakan media tersebut.

\section{DAFTAR PUSTAKA}

Arsyad, Azhar. Media Pengajaran. Jakarta : PT Raja Grafindo Persada, 2000.

Asmani, Jamal Ma'mur. Tips Menjadi Guru Insfiratif, Kreatif dan Inovatif.Jogjakarta : DIVA Press, 2009.

Hamalik, Oemar. Media pendidikan. Bandung: PT Rosdakarya, 1982.

, Proses Belajar Mengajar. Jakarta: PT Bumi Aksara, 2008.

, Kurikulum dan Pembelajaran. Jakarta

: PT Bumi Aksara, 2009.

Hamid, Moh. Sholeh. Standart Mutu Penilaian dalam Kelas. Jogjakarta: DIVA Pres, 2011.

Hasbuan, J.J. Proses Belajar Mengajar. Bandung: PT Remaja Rosdakarya, 2009.

Munadi, Yudhi. Media Pembelajaran. Jakarta: Gaung Persada Press, 2008.

Soebahar, Abd. Halim. Kebijakan Pendidikan Islam. Jember: Pena Salsabila, 2012.

Sudjana, Nana. Dasar-Dasar Proses Belajar Mengajar. Bandung: Sinar Biru Grafindo, 2013.

Uno, Hamzah B. Model pembelajaran. Jakarta: PT Bumi Aksara, 2009. 
Usman, Moh. Uzer. Menjadi Guru Profesional. Bandung: Remaja Rosdakarya, 2004.

Yamin, Martinis. Manejemen Pembelajaran Kelas. Jakarta:

Gaung Persada, 2009. 